JURNAL EINSTEIN
Jurnal Hasil Penelitian Bindang Fisika
$\begin{gathered}\text { Available online http://jurnal.unimed.ac.id/2012/index.php/inpafi } \\ \text { e-issn: } 2407-747 x, p-i s s n 2338-1981\end{gathered}$

\title{
Pengaruh Variasi Ukuran Butiran Pasir Merah Labuhan Batu Selatan Untuk Meningkatkan Kekuatan Beton
}

\author{
Fadillah Ulfa Nasution dan Mukti Hamjah Harahap
}

Jurusan Fisika, Fakultas Matematika dan Ilmu Pengetahuan Alam, Universitas Negeri Medan, Indonesia

fadillahulfanasution@gmail.com

Diterima Desember 2016; Disetujui Januari 2017; Dipublikasikan Februari 2017

\begin{abstract}
ABSTRAK
Penelitian ini bertujuan untuk mengetahui pengaruh penambahan pasir merah ukuran 80 mesh, 100 mesh, dan 120 mesh terhadap nilai kuat tekan dan daya serap air beton. Metode pembuatan yang dilakukan adalah SNI 03-2834-2000 yang mengacu pada pembuatan beton mutu K-175 dengan komposisi campuran semen : pasir : kerikil adalah $1: 2: 3$ dengan FAS 0,5. Beton dibuat berbentuk kubus $15 \times 15 \times 15 \mathrm{~cm}$. Pada penelitian ini dibuat variasi komposisi pasir merah sebesar 80 mesh, 100 mesh, dan 120 mesh. Setelah beton berumur 24 jam cetakan dibuka dan diberi nomor kode sesuai yang diinginkan dan dirawat dalam bak air. Setelah melalui masa perendaman 28 hari kemudian beton diuji dengan metode uji kuat tekan dan daya serap air. Dari hasil pengujian diperoleh sifat mekanik yaitu kuat tekan beton minimumnya yaitu pada penambahan pasir merah 120 mesh yaitu rata-rata $13.36 \mathrm{MPa}$, sedangkan kuat tekan beton maksimum pada penambahan pasir merah 80 mesh yaitu rata-rata 15,61 MPa. Dari hasil pengujian daya serap air terjadi penurunan pada beton dengan penambahan pasir merah pada ukuran 80 mesh (sampel B) dan 120 mesh (sampel D) yaitu 50\%. Hal ini dapat disimpulkan bahwa variasi ukuran butir lebih efektif untuk menurunkan daya serap air.
\end{abstract}

Kata kunci : Pasir merah 80 mesh, Pasir Merah 100 mesh, Pasir Merah 120 mesh, Kuat Tekan, Daya Serap Air.

\section{PENDAHULUAN}

Perkembangan teknologi dan kemajuan industri yang semakin berkembang pesat memacu peningkatan pembangunan disegala sektor kehidupan, seiring dengan peningkatan jumlah populasi penduduk kebutuhan akan rumah juga meningkat. Rumah sebagai tempat tinggal merupakan kebutuhan primer setelah makanan dan pakaian (Aryadi,2010). Rumah sekarang banyak mengalami kerusakan akibat gempa. Kerusakan tersebut seperti hancur dan retak-retak pada dinding beton rumah, hal ini terjadi karena ikatan agregat pada beton tidak solid atau tidak kuat. Pasir Merah Labuhan Batu Selatan digunakan sebagai bahan campuran pembuatan beton karena memiliki kandungan seperti $\mathrm{SiO}_{2}$ (silikon Oxide), $\mathrm{TaO}_{2}$ (Tantalum Oxide), $\mathrm{FeNi}$ (Iron Nikel), $\mathrm{FeC}$ (Iron Carbide), $\mathrm{TaO}$ (Tantalum Oxide), $\mathrm{Fe}_{2} \mathrm{C}$ (Iron Carbide) dan nilai intensitas silikon pasir merah tinggi. (Harahap, 2013). $\mathrm{SiO}_{2}$ merupakan salah satu unsur kimia terbesar yang terkandung dalam semen Portland, sehingga dengan unsur ini akan 
lebih memungkinkan didapatkannya campuran beton yang lebih kuat.

Berdasarkan uraian diatas, masalahnya adalah ikatan agregat yang tidak kuat. Untuk memperbaiki ikatan agregat ada beberapa metode yang dapat dilakukan, antara lain metode Standar Nasional Indonesia (SNI), American Society for Testing and Materials (ASTM), American Association of State Highway and Transportation Offical (AASHTO). Metode yang tepat untuk dilakukan perbaikan terhadap agregat beton yaitu metode SNI. Metode SNI yang dilakukan adalah SNI 152049-2004 (Pemakaian semen), SNI 03-28342000 (Pembuatan Campuran Beton Normal), SNI 03-2834-2000 (Tata Cara Pembuatan Dan Perawatan Beton) SNI 03-1974-1990 (Pengujian Kuat tekan) kuat tekan beton adalah besarnya beban persatuan luas yang menyebabkan benda uji beton hancur bila dibebani dengan gaya tekan tertentu, yang dihasilkan oleh mesin tekan, untuk mendapatkan benda uji harus diikuti beberapa tahapan dari beton segar yang mewakili campuran beton. Isi cetakan dengan adukan beton dalam 3 lapis, dimana setiap lapis didapatkan dengan 25x tusukan secara merata, setelah itu ratakan permukaan beton dan tutuplah dengan bahan kedap air. Kemudian biarkan 24 jam, setelah itu bukalah cetakan dan keluarkan benda uji, lalu rendam dalam bak perendaman berisi air pada temperature $25^{\circ} \mathrm{C}$ (Cahyadi, 2012).

Penelitian Agustina (2012) tentang pembuatan beton dengan penambahan pasir merah Labuhan Batu Selatan dengan variasi $50 \%$ pasir merah dan $50 \%$ pasir biasa menghasilkan beton yang memiliki kuat tekan $32 \mathrm{MPa}$. Dengan variasi volume pasir merah Labuhan Batu Selatan 50\% dan 50\% volume pasir biasa dengan metode SNI 03-2834-2000 (Pembuatan Campuran Beton Normal) menghasilkan kuat lentur yang lebih bagus dibandingkan dengan menggunakan variasi komposisi pasir merah 25\% dan 75\% (Harahap, 2013). Penelitian mengenai penggunakan pasir laut sebagai campuran beton menghasilkan kuat tekan 28,28 $\mathrm{MPa}$, pasir laut merupakai pasir yang paling jelek karena kandungan garamgaramnya . Garam ini menyerap air dari udara dan ini menyebabkan pasir selalu basah dan menyebabkan pengembangan bila sudah menjadi bangunan (Yufiter Silas Kandi, dkk., 2012).

\section{METODOLOGI PENELITIAN}

Metode yang digunakan dalam penelitian ini adalah SNI 03-2834-2000 yang mengacu pada pembuatan beton mutu K-175. Variabel yang mempengaruhi kuat tekan beton ditinjau dari aspek variasi ukuran butiran pasir merah , sedangkan faktor-faktor yang lain seperti susunan gradasi, cara pemadatan dan perawatan selama proses pengerasan digunakan cara-cara standar Nasional Indonesia (SNI). Dalam penelitian ini pelaksanaannya dibagi dalam beberapa tahap. Tahap pertama persiapan, tahap pengujian bahan, tahap pengujin benda uji dan pengolahan data.

Bahan-bahan yang digunakan dalam penelitian ini yaitu semen Portland, agregat halus (pasir merah, pasir biasa), agregat kasar, air. Pasir merah ini diperoleh dari desa Padang Bulan kecamatan Kota Pinang kabupaten Labuhan Batu Selatan. Sedangkan peralatan yang digunakan anatara lain Stone cruser, Neraca analitik, Gelas ukur, Tongkat pemadat, Sendok semen, Ayakan screen, Cetakan beton, Molen, Oven, Compress Testing Machinedan Ember.

\section{Prosedur Pembuatan Sampel}

Proses pembuatan sampel diawali

dengan menyediakan bahan campuran beton yaitu Semen Portland tipe I, pasir merah, pasir sungai, semen dan air kemudian pasir merah digiling menggunakan mesin stone cruser, menjemur pasir merah lalu Mengayak pasir merah dengan ayakan 80 mesh, 100 mesh, 120 mesh, dan pasir sungai, dilanjutkan dengan membersihkan alat-alat yang akan digunakan, kemudian kita menakar bahan baku sesuai dengan komposisi yang telah dibuat serta menstel cetakan beton. Selanjutnya, mesin molen dihidupkan mula-mula dituangkan semen, agregat halus dan kerikil. Sambil mencampur bahan-bahan tersebut dilanjutkan dengan penambahan air sedikit demi sedikit, Setelah campuran dalam molen merata, campuran yang berada dalam molen dituang ke 
ember besar dan kemudian kita masukkan campuran tersebut ke dalam cetakan beton.

Campuran dalam cetakan kemudian dipadatkan dan setelah itu didiamkan selam 24 jam lalu kemudian cetakan dibuka. Sampel beton yang telah dibuka dirawat di dalam bak perendaman selama 28 hari selanjutnya dikeringkan selam 2 hari. Sampel beton yang telah dikeringkan kemudian diuji.

\section{Karakterisasi Beton}

Untuk mengetahui sifat-sifat dan kemampuan suatu material maka dalam penelitian ini dilakukan pengujian, yaitu pengujian daya serap air dan kuat tekan.

\section{Tekanan}

Besarnya tekanan beton ditentukan oleh pengaturan dari perbandingan semen, agregat kasar dan halus, air dan berbagai jenis campuran. Perbandingan dari air terhadap semen merupakan faktor utama didalam penentuan kekuatan beton (Murdock dan Brook, 1991). Semakin rendah perbandingan air-semen, semakin tinggi kekuatan tekan. Suatu jumlah tertentu air diperlukan untuk memberikan aksi kimiawi di dalam pengerasan beton, kelebihan air meningkatkan kemampuan pengerjaan akan tetapi menurunkan kekuatan (Wang dalam Suseno,dkk, 2008).

\section{Daya serap air}

Besar kecilnya penyerapan air sangat dipengaruhi pori atau rongga yang terdapat pada beton. Semakin banyak pori yang terkandung dalam beton maka akan semakin besar pula penyerapan sehingga ketahanannya akan berkurang

\section{Hasil Penelitian}

\section{HASIL DAN PEMBAHASAN}

Pembuatan beton yang dibuat dengan campuran semen, pasir, pasir merah, kerikil dan air dirawat selama 28 hari dan pengeringan selama dua hari lalu kemudian dilakukan pengujian daya serap air dan juga tekanan. Karakteristik beton yang dihasilkan ternyata sangat dipengaruhi oleh bahan tambah yang diberikan ke dalam campuran beton atau bahan baku penyusun beton serta perawatan dan pengeringan beton. Mutu beton K-175 campuran beton atau bahan baku penyusun beton serta perawatan dan pengeringan beton. Mutu beton K-175 dalam hal ini dilakukan pembuatan beton dengan perbandingan $1: 2: 3$. Untuk mengetahui karakteristik beton tersebut maka perlu dilakukan pengujian sifat fisis dan sifat mekanis beton yaitu daya serap air dan tekanan beton.

\section{Pembahasan}

Daya Serap Air

Besar kecilnya penyerapan air oleh beton dipengaruhi pori atau rongga yang terdapat pada beton. Semakin banyak pori yang terkandung dalam beton maka semakin besarpula penyerapan sehingga ketahanan akan berkurang. Rongga (pori) yang terdapat pada beton terjadi karena kurang tepatnya kualitas dan komposisi material penyusunannya.

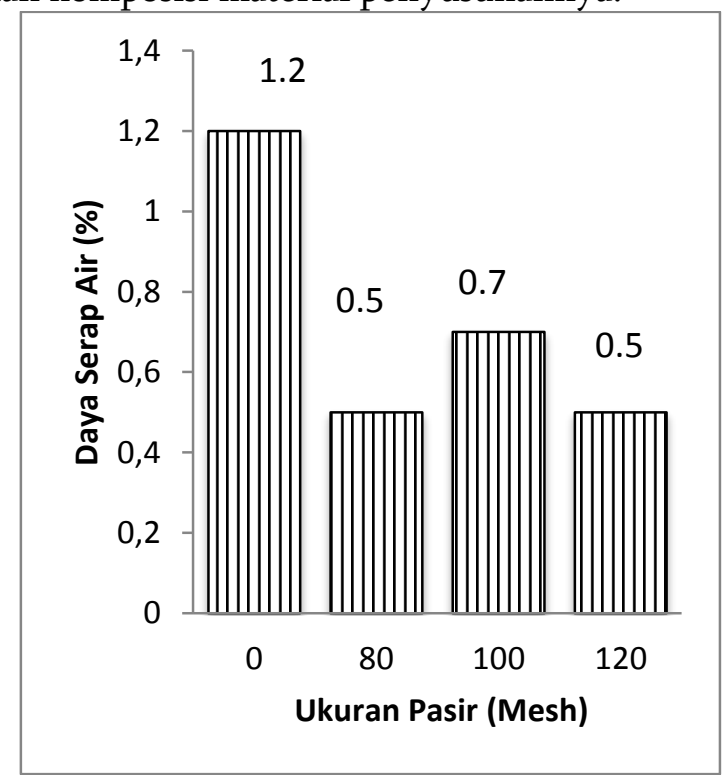

Gambar 1. Grafik hubungan sampel terhadap daya serap air(\%).

Pada gambar 1. menunjukkan bahwa daya serap air berkurang seiring dengan penambahan pasir merah. Pasir merah dengan ayakan 80 mesh dan 120 mesh memiliki daya serap air sebesar $0.5 \%$. Namun pada penambahan pasir merah dengan ukuran ayakan 100 mesh memiliki daya serap yang lebih tinggi yaitu $0.7 \%$. Beton dengan pencampuran pasir merah dari Labuhan Batu Selatan pada variasi ukuran butir memiliki daya serap yang jauh lebih rendah dibandingkan dengan beton 
normal dan beberapa penelitian sebelumnya yaitu $0.5 \%$.

\section{Tekanan}

Pengujian tekanan beton dilakukan untuk melihat apakah beton memiliki kekuatan yang memenuhi persyaratan yang direncanakan. Tabel 4.1. Tabel hasil pengujian kekuatan tekan beton

\begin{tabular}{cccc}
\hline $\begin{array}{c}\text { Variasi } \\
\text { ukuran } \\
\text { butir } \\
(\mathrm{mesh})\end{array}$ & $\begin{array}{c}\text { Luas } \\
\text { Permukaan } \\
\text { rata-rata } \\
\left(\mathbf{m}^{2}\right)\end{array}$ & $\begin{array}{c}\text { Beban } \\
\text { tekan } \\
\text { rata-rata } \\
(\mathrm{kN})\end{array}$ & $\begin{array}{c}\text { Kuat } \\
\text { tekan } \\
\text { rata-rata } \\
(\mathrm{MPa})\end{array}$ \\
\hline $\mathbf{0}$ & 0,0225 & 399.07 & 17.74 \\
$\mathbf{8 0}$ & 0,0225 & 351.30 & 15.61 \\
$\mathbf{1 0 0}$ & 0,0225 & 305.78 & 13.59 \\
$\mathbf{1 2 0}$ & 0,0225 & 300.68 & 13.36 \\
\hline
\end{tabular}

Berdasarkan tabel 4.1. dapat dilihat tanpa menggunakan pasir merah memiliki nilai kuat tekan rata-rata $17.74 \mathrm{MPa}$, dengan ukuran 80 mesh memiliki nilai kuat tekan rata-rata 15.61 $\mathrm{MPa}$, ukuran 100 mesh memiliki nilai kuat tekan rata-rata $13.59 \mathrm{MPa}$ dan dengan ayakan 120 mesh memiliki nilai kuat tekan ratarata $13.36 \mathrm{MPa}$. Selain itu komposisi agregat halus yang digunakan dalam pembuatan beton ini adalah $50 \%$ pasir biasa dan $50 \%$ pasir merah ini menurut penelitian (Harahap, 2013)

\section{Kesimpulan}

\section{KESIMPULAN DAN SARAN}

Dari hasil pengujian uji tekan beton dengan variasi ukuran butiran pasir merah di peroleh pada sampel B memiliki kuat tekan yang terbesar dibandingkan dengan sampel C dan $\mathrm{D}$ yaitu sebesar $15.61 \mathrm{Mpa}$, hal ini disebabkan karena ukuran butiran pada sampel B relatif sama dengan ukuran butiran pasir merah yang sebelum diproses.

Berdasarkan hasil uji daya serap air pada beton memiliki kelinieran hasil pada uji kuat tekan, dimana penambahan pasir merah dengan ukuran ayakan 80 mesh (sampel B) memiliki kuat tekan yang lebih tinggi dibanding dengan variabel lain. Ini menunjukan kerapatan yang baik pada beton tersebut. Pasir merah dengan ayakan 80 mesh (sampel B) dan 120 mesh (sampel D) memiliki daya serap air sebesar $0.5 \%$. Namun pada penambahan pasir merah dengan ukuran ayakan 100 mesh (sampel C) memiliki daya serap yang lebih tinggi yaitu 0.7 $\%$.

\section{Saran}

1. Perlu adanya perhatian yang lebih teliti untuk peneliitian selanjutnya dalam proses mixing atau pencampuran beton yang lebih baik lagi agar tercapai kehomogenan campuran guna meningkatkan kuat tekan betonnya

2. Ada baiknya untuk penelitian selanjutnya perlu dilakukan adanya variasi penambahan pasir merah yang lebih rinci agar diperoleh data yang baik untuk daya serap air dan kuat tekan beton.

\section{DAFTAR PUSTAKA}

Agustina, (2012), Pengaruh Penambahan Volume Pasir Merah Labuhan Batu Selatan Terhadap Massa Jenis, Daya Serap Air, Serta Kuat Tekan Beton, Skripsi, FMIPA, UNIMED, Medan.

Badan Standarisasi Nasional, (1990),SNI O31974-1990, Metode Pengujian Kuat Tekan Beton. Jakarta, BSN.

Badan Standarisasi Nasional, (2000), SNI 032834-2000, Tata Cara Pembuatan Rencana Campuran Beton Normal, Jakarta, BSN.

Dumbi, Pratiwi, (2014), Pengaruh Penambahan Material Halus Bukit Pasolo Sebagai Pengganti Sebagian Pasir Terhadap Kuat Tekan Beton, Jurnal Teknik Sipil. 1(4),1-8.

Harahap, V., (2010), Pengaruh Karakteristik Pasir Merah Labuhan Batu Selatan Terhadap Sifat Mekanik (Uji Sem, Difraksi Sinar X, Uji Impak) Dari Beton, Skripsi, Fmipa, Unimed, Medan.

Mulyono, T., (2003, 2004, 2005), Teknologi Beton, Penerbit: Andi, Yogyakarta.

Murdock, L.J., and BROOK, K.M., (1991), Bahan-Bahan Dan Praktek Beton, Edisi Keempat, Penerbit: Erlangga, Jakarta. 